\title{
Leaf traits of Brazilian semiarid species as regulatory factors for associated aquatic invertebrates
}

\author{
Marcos MEDEIROS CAVALCANTI JÚNIOR, ${ }^{*}{ }^{*}$ Luiz U. HEPP, ${ }^{2}$ Joseline MOLOZZI, ${ }^{3}$ Dilma M. de Brito Melo TROVÃO ${ }^{4}$
}

${ }^{1}$ Postgraduate program in Ecology, University of Brasilia; ${ }^{2}$ Department of Biological Sciences, Integrated Regional University of Alto Uruguai and Missões, Erechim, Rio Grande do Sul; ${ }^{3}$ Postgraduate program in Ecology and Conservation, Department of Biological Sciences, State University of Paraiba, Campina Grande, Paraiba; ${ }^{4}$ Postgraduate program in Ecology and Conservation, Department of Biological Sciences, State University of Paraiba, Campina Grande, Paraiba, Brazil

*Corresponding author: medeiroscavalcantijr@gmail.com

\begin{abstract}
The input of leaf litter is an important energy source for the riparian vegetation of aquatic ecosystems, and the chemical composition of leaf litter is decisive for colonization by invertebrates in streams. Plant species of the semiarid regions present different morphophysiological characteristics to combat the effects of drought, including tough leaves that have less nutritional quality. However, although concern regarding the decomposition of organic matter in aquatic ecosystems in semiarid regions is increasing, no information exists on the influence of leaf traits (e.g., $\mathrm{N}, \mathrm{C}: \mathrm{N}$ ratio and toughness) before the colonization of invertebrates and the decomposition of leaf litter. We hypothesized that: i) leaves with greater toughness, higher C:N ratio and lower amount of $\mathrm{N}$ present low density and biomass of associated invertebrates; ii) greater density and biomass of associated invertebrates results in increased decomposition rates; and iii) leaf traits influences the structure and composition of functional feeding groups of associated invertebrates. We incubated senescent leaves of Tabebuia aurea and Aspidosperma pyrifolium in a Brazilian semiarid stream using litter bags, and after 3, 7, 15 and 30 days, four litter bags were withdrawn for laboratory washing of the remaining leaf sediment and for collection of associated invertebrates. A. pyrifolium leaves presented higher nutritional quality (low C:N ratio, lower toughness), and the decomposition rate was higher than $T$. aurea leaves. Invertebrate density and biomass varied among litter, being higher in T. aurea and A. pyrifolium, respectively. The leaf litter quality also altered the composition of functional feeding groups. We observed a higher density of filters on T. aurea and collectors on A. pyrifolium. Both T. aurea and A. pyrifolium presented higher biomass of collectors, however $T$. aurea showed higher biomass of filters than $A$. pyrifolium. In the absence of shredders, leaf litter may have been used by invertebrates as a substrate, for shelter against predators and current, and sporadically as a food resource. Thus, differences in the leaf traits were important structures of the streams invertebrate. These are the first results of the influence of leaf traits on invertebrate colonization in the streams of semiarid regions, and reinforce the need for studies to verify the contribution of organic matter as well as the feeding preferences of invertebrates.
\end{abstract}

Key words: Biomass; decomposition; functional feeding group; riparian zones; toughness.

Received: December 2017. Accepted: April 2018.

\section{INTRODUCTION}

The input of allochthonous organic matter is an important energy source for the riparian vegetation of aquatic ecosystems (Vannote et al., 1980; Marcarelli et al., 2011). Much of allochthonous organic matter that enters these ecosystems consists of leaves (Gonçalves and Callisto, 2013) that are processed, which constitute the basis of aquatic food webs (Vannote et al., 1980; Frauendorf et al., 2013). The decomposition of leaf litter in streams is related to environmental (e.g., current velocity, $\mathrm{pH}$, dissolved oxygen and nutrients) and biotic factors (e.g., microrganisms and invertebrates) interacting over time, and leaf traits are related to the physical structure and chemical composition of the leaves (e.g., toughness, nitrogen and polyphenols) (Tank et al., 2010; García-Palacios et al., 2016).
The chemical composition of leaf litter is important for colonization by invertebrates in streams ( $\mathrm{Li}$ et al., 2009). Among the most important chemical compounds, the concentrations of carbon $(\mathrm{C})$, nitrogen $(\mathrm{N})$ (Pettit et al., 2012), and the C:N ratio (Graça and Cressa, 2010) are conventionally used to quantify the parameters of the food quality of leaf litter regarding invertebrates. Thus, aquatic invertebrates can respond to variations in leaf quality as assessed by their affinity and speed of colonization in the litter (Graça et al., 2001).

Leaf toughness has also been identified as an important structural feature that determines the colonization of invertebrate on leaf litter in tropical streams (Li et al., 2009), since tough leaves hinder the consumption by invertebrates (Graça et al., 2001). In regions with water stress, such as dry tropical forests, leaf traits such as specific leaf area, toughness and the C:N 
ratio strongly influence the ability of plants to acquire, use and conserve resources, influencing how plants respond to environmental stresses such as water deficit and herbivory (Pringle et al., 2011). The leaves of evergreen species present a lower specific leaf area and a higher C:N ratio, compared with the leaves of species that lose their leaves during the dry period in seasonally dry tropical forests (Pringle et al., 2011). Furthermore, defence against herbivores in tropical regions also influences other characteristics, such as leaf production and the accumulation of secondary metabolites (e.g., alkaloids and tannins), and increases leaf toughness (Coley and Barone, 1996), reducing leaf palatability to consumers.

Semiarid regions occupy about $15 \%$ of the planet's surface (Safriel and Adeel, 2005). These regions must combat the effects of the climate change more effectively due to the increase in temperature and reduction in rainfall, leading to more droughts in the coming decades (Marengo, 2015). In this context, the vegetation of semiarid regions must undergo changes with the greatest water unavailability (IPCC, 2012, 2014). In addition, human activities will enhance the negative effects on ecosystem services caused by climate change (Safriel and Adeel, 2005).

In semiarid regions, most studies on leaf litter decomposition have been performed in terrestrial environments (Cepeda-Pizarro, 1993; Sherman et al., 2014; Bernaschini et al., 2016). Although concern regarding the decomposition of organic matter in aquatic ecosystems in semiarid regions is increasing, no information exists on the influence of leaf traits (e.g., N, C:N ratio and toughness) before the colonization of invertebrates and the decomposition of leaf litter. In this study, we evaluated the influence of the structural and chemical characteristics of the leaves of two species that are widely present in the riparian forests of the Brazilian semiarid region on invertebrate colonization during decomposition in a stream. We first hypothesised that we would observe a higher density and biomass of organisms in the litter of better nutritional quality (high $\mathrm{N}$ concentration and lower $\mathrm{C}: \mathrm{N}$ ratio) and lower toughness. Next, we tested the hypothesis that increased density and biomass of invertebrates in the leaf litter of better quality and lower toughness would result in faster leaf decomposition rates. Finally, we tested whether the quality and toughness of the leaf litter would influence the composition of functional feeding groups of invertebrates associated with the litter, particularly by increasing the density and biomass of scrapers and shredders.

\section{METHODS}

\section{Study area}

We performed the experiment during August and September of 2015 in the Pataxó stream (5³6’25”S, $\left.36^{\circ} 50^{\prime} 35^{\prime \prime} \mathrm{W}\right)$, which belongs to the catchment area of the Piancó/Piranhas/Açú Rivers in north-eastern Brazil (Fig. 1). The region consists of a BSh climate and is characterised as a low-altitude and latitude semiarid region (Alvares et al., 2013). In the year of the experiment, the rainfall index of the area reached the maximum values in March (approximately $180 \mathrm{~mm}$ ) and the minimum values in the period from July to December, during which there was no record of rainfall in the region (ANA, 2016).

Pataxó stream is a third-order stream that is approximately $5 \mathrm{~m}$ wide and $0.35 \mathrm{~m}$ deep. The substrate is composed of mostly rocks and gravel. The riparian vegetation extends $30 \mathrm{~m}$ on both sides. During the experiment, the average water temperature was $26.8^{\circ} \mathrm{C} \pm 0.3$ (mean \pm standard deviation). The electrical conductivity was low $\left(9.3 \pm 0.1 \mu \mathrm{S} \mathrm{cm}^{-1}\right)$, and the water had a basic $\mathrm{pH}(9.3 \pm 0.1)$ and was well oxygenated $\left(8.6 \pm 0.2 \mathrm{mg} \mathrm{L}^{-1}\right)$. The ammonia concentration in the water was $81.2 \pm 8.0 \mu \mathrm{g} \mathrm{L}^{-1}$, and the total phosphorus was $96.0 \pm 3.9 \mathrm{mg} \mathrm{L}^{-1}$. The average current velocity of the stream was $1.93 \pm 0.06 \mathrm{~m} \mathrm{~s}^{-1}$.

\section{Field experiment}

We used the senescent leaves of both Tabebuia aurea (Silva Manso) Benth. \& Hook. F. ex S. Moore (Bignoniaceae) and Aspidosperma pyrifolium Mart. (Apocynaceae), which are common native trees in riparian forests of the region (Bessa and Medeiros, 2011; Oliveira et al., 2013). The leaves were collected during the months of March to June 2015 with nets $1 \mathrm{~m}$ above the ground in a forest fragment in the Brazilian semiarid region $\left(7^{\circ} 20^{\prime} 11^{\prime \prime} \mathrm{S}, 36^{\circ} 26^{\prime} 52^{\prime \prime} \mathrm{W}\right)$. We dried the leaves at room temperature $\left(25^{\circ} \mathrm{C}\right)$ in the shade for 5 days and then weighed $3.0 \pm 0.1 \mathrm{~g}$ of leaves for incubation in litter bags $(17 \times 13 \mathrm{~cm} ; 10 \mathrm{~mm}$ mesh). Afterward, we incubated 32 litter bags ( 2 leaf species $\times 4$ sample times $\times 4$ replicates), and after 3, 7, 15 and 30 days, we removed four litter bags of each species for laboratory washing of the remaining leaf sediment and for collection of associated invertebrates.

\section{Leaf litter traits}

We performed initial structural and chemical analyses of the leaf litter to characterise the leaves of the species used. To obtain the specific leaf area and leaf toughness, we extracted 12-mm-diameter leaf discs from each species, avoiding the central vein. We then divided the leaf area of the disc by the dry mass (obtained by drying the material in a muffle furnace $\left(550^{\circ} \mathrm{C}\right.$ for $\left.5 \mathrm{~h}\right)$ to obtain the specific leaf area. To estimate leaf toughness, we measured the force required for a metal needle to pierce the central region of the leaf disc (Graça and Zimmer, 2005). The leaf discs were placed between two bases with 
a central rod supporting a glass beaker; therefore, the leaf toughness represented the force exerted by the mass of water deposited in the glass beaker required for the metal blade to pierce the leaf. To determine the remaining mass and calculate the decomposition rates, we dried the samples of litter in a greenhouse $\left(40^{\circ} \mathrm{C}\right.$ for $\left.72 \mathrm{~h}\right)$, placed them in a muffle furnace $\left(550^{\circ} \mathrm{C}\right.$ for $\left.4 \mathrm{~h}\right)$ and then weighed them using a precision scale.

We measured leaf $\mathrm{C}$ content from the proportion of $47 \%$ of the ash-free dry mass of the leaf sample obtained from the muffle furnace $\left(550^{\circ} \mathrm{C}\right.$ for $\left.5 \mathrm{~h}\right)$ (Westlake, 1963). The $\mathrm{N}$ concentration was determined in accordance with the Kjeldahl method (Bataglia et al., 1983). Consequently, the $\mathrm{C}: \mathrm{N}$ ratio of the leaf litter was obtained based on the $\mathrm{C}$ and $\mathrm{N}$ leaf content initially quantified. We measured the tannin content in accordance with the Folin-Denis method (Anderson and Ingram, 1996). The $\mathrm{Ca}, \mathrm{Mg}$ and $\mathrm{K}$ contents were measured using atomic absorption spectrometry from the extraction of nitric acid with the inorganic litter fraction (reproducibility $>93 \%$ ).

\section{Laboratory procedures}

In the laboratory, we washed the leaf litter using a sieve having $250 \mu \mathrm{m}$ of mesh opening to retain associated organisms. Invertebrates removed from the litter were fixed in $70 \%$ alcohol and identified at the family level, with the exceptions of Chironomidae larvae and Trichoptera, which were identified at the genus level with the aid of taxonomic keys (Fernandez and Domingues, 2001; Mugnai et al., 2010; Trivinho-Strixino, 2011). We grouped invertebrates into functional feeding groups in accordance with the classification proposed by Wantzen and Wagner (2006). To estimate biomass, we dried the invertebrates $\left(60^{\circ} \mathrm{C}\right.$ for $\left.72 \mathrm{~h}\right)$, and organisms belonging to the Mollusca group were also dried in a muffle furnace $\left(550^{\circ} \mathrm{C}\right.$ for $\left.4 \mathrm{~h}\right)$.

\section{Data analysis}

Initially, we tested the normality of the data using the Shapiro-Wilk normality test and an F-test. Moreover,

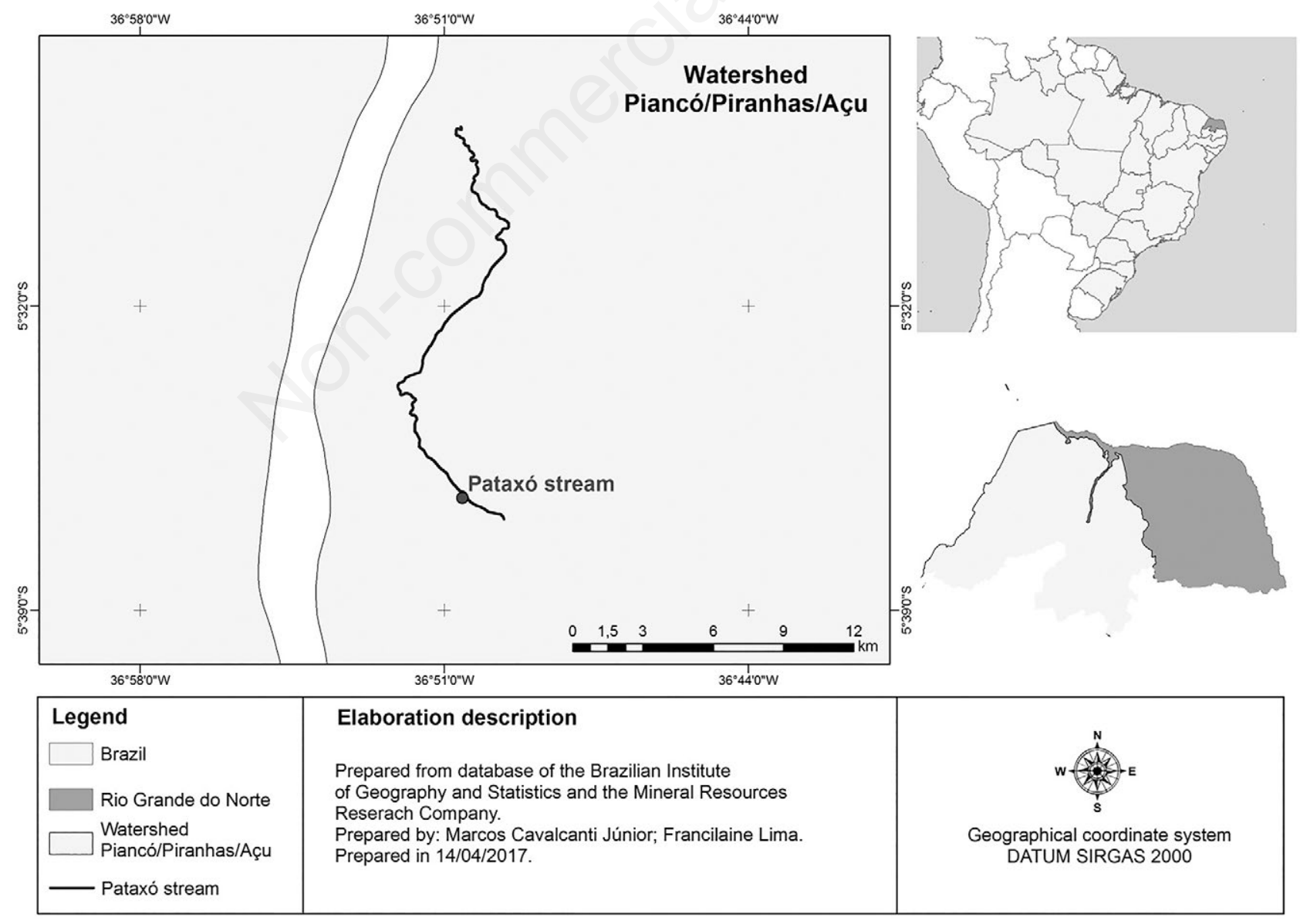

Fig. 1. Localization of the study area in Rio Grande do Norte, north-eastern semiarid Brazil. 
when necessary, the data were transformed $(\log x+1)$. To verify differences in the leaf-litter quality, we used a $t$ test. In order to determine the coefficient of decomposition of the litter, we used the negative exponential model of $\mathrm{W}_{\mathrm{t}}=\mathrm{W}_{0} \times \mathrm{e}^{-\mathrm{kt}}$, where $\mathrm{W}_{\mathrm{t}}$ is the remaining weight of the debris in time (days), $\mathrm{W}_{0}$ is the initial weight, and $\mathrm{k}$ is the decomposition coefficient (Webster and Benfield, 1986). To verify the variation in the decomposition rate among the litter, we used an analysis of covariance (ANCOVA), whose covariant was leaf incubation time. We used non-metric multidimensional scaling (NMDS) ordination (BrayCurtis dissimilarity matrix) to assess the similarity between sample units (litter bags), considering plant species and time of incubation as factors. The differences in density and biomass of associated invertebrates and functional feeding groups were analysed using two-way analysis of variance (ANOVA) with the Tukey's HSD test. To assess the patterns of the composition of the functional trophic groups of the invertebrates between tree species, we used Permutational Multivariate Analysis of Variance (PerMANOVA). All analyses were performed using the 'R' software program (R Core Team, 2016).

\section{RESULTS}

\section{Mass loss and leaf traits}

Mass loss differed between species and between the incubation time in the stream (ANCOVA, $\mathrm{F}_{2,33}=35.6$; $\mathrm{P}<0.0001$ ). After 30 days of the experiment, the leaves of T. aurea lost approximately $90 \%$ of their initial mass $(k=$ -0.078 day $^{-1}$ ). The leaves of A. pyrifolium lost $100 \%$ between the $7^{\text {th }}$ and $15^{\text {th }}$ days of the experiment $(k=-0.165$ day $^{-1}$ ) (Fig. 2).

The studied leaf species differed with respect to their structural and chemical characteristics (Tab. 1). The structural characteristics were the most discrepant. The leaf litter of T. aurea had greater toughness, whereas the leaf litter of $A$. pyrifolium had a greater specific leaf area. $\mathrm{N}$ and $\mathrm{C}$ concentrations were higher in A. pyrifolium, reflecting a lower $\mathrm{C}: \mathrm{N}$ ratio. Furthermore, the $\mathrm{Ca}$ and $\mathrm{Mg}$ contents were higher in A. pyrifolium, whereas the $\mathrm{K}$ content was higher in $T$. aurea. Only the concentrations of tannins were similar between the species studied.

\section{Leaf litter-associated invertebrates}

A total of 2525 invertebrates were found to be associated with the leaf litter of the two species during the experiment. The taxa that occurred between both plant species throughout the experiment included the Baetidae, Leptohyphidae, Smicridea, Tanytarsus and Ubatubaneura. However, Tanytarsus occurred in high

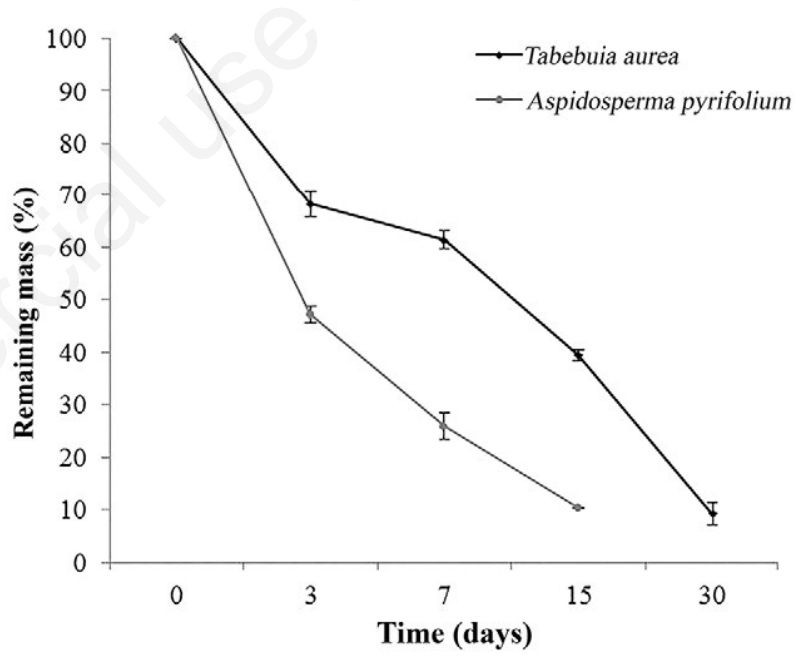

Fig. 2. Remaining mass (\%) of Tabebuia aurea and Aspidosperma pyrifolium incubated in a Brazilian semiarid stream. The bars represent the standard error.

Tab. 1. Leaf traits of Tabebuia aurea and Aspidosperma pyrifolium (mean $\pm \mathrm{SD}$ ) and values of the $t$-test. Values in bold indicate the variables showing significant differences.

\begin{tabular}{|c|c|c|c|c|}
\hline Variables & Tabebuia aurea & Aspidosperma pyrifolium & t & $\mathbf{P}$ \\
\hline Toughness (kPa) & $5883.3 \pm 2221.6$ & $153.7 \pm 1.8$ & 17.4 & $<0.001$ \\
\hline Specific leaf area $\left(\mathrm{mm}^{2} \mathrm{mg}^{-1}\right)$ & $6.3 \pm 0.2$ & $13.1 \pm 1.1$ & -5.9 & 0.023 \\
\hline Carbon (\%) & $0.7 \pm 0.0$ & $1.0 \pm 0.1$ & -8.8 & 0.002 \\
\hline Nitrogen $(\%)$ & $0.5 \pm 0.0$ & $1.2 \pm 0.0$ & -32.6 & $<0.001$ \\
\hline $\mathrm{C}: \mathrm{N}$ ratio & $1.3 \pm 0.1$ & $0.8 \pm 0.0$ & 6.6 & 0.002 \\
\hline Tannins $\left(\mathrm{mg} \mathrm{g}^{-1}\right)$ & $4.2 \pm 0.1$ & $4.1 \pm 0.2$ & 0.6 & 0.580 \\
\hline Calcium (mg g $\mathrm{g}^{-1}$ ) & $5.2 \pm 0.7$ & $13.7 \pm 0.5$ & -9.3 & 0.001 \\
\hline Magnesium $\left(\mathrm{mg} \mathrm{g}^{-1}\right)$ & $1.6 \pm 0.2$ & $7.0 \pm 0.3$ & -14.6 & $<0.001$ \\
\hline Potassium $\left(\mathrm{mg} \mathrm{g}^{-1}\right)$ & $130.3 \pm 29.4$ & $38.3 \pm 3.3$ & 4.3 & 0.035 \\
\hline
\end{tabular}


density at day 30 in T. aurea litter. In days 3,7 and 15 of the experiment had the same taxa for both species; however, their densities differed. On day 7, A. pyrifolium litter showed lower density of Tanytarsus and Thyrididae, whereas T. aurea litter had the lowest density of Smicridea on day 3. The day 30 was different with respect to the permanence of $T$. aurea leaves, and some taxa, such as Hydroptila, Ancylidae, Sphaeriidae, Acarina and Oligochaeta, were recorded only at this period.

There was a difference between the two leaf species when comparing the invertebrate density and biomass (Tab. 2, Fig. 3). Density varied among species and time, but biomass only varied among species (interaction, Tab. 2).

Overall, Ephemeroptera was the order that presented the highest density values on both species $T$. aurea and $A$. pyrifolium. Chironomidae (Diptera) was the family with the highest density on T. aurea, followed by Baetidae (Ephemeroptera) and Hydroptilidae (Trichoptera). Baetidae (Ephemeroptera) presented higher density on A. pyrifolium, followed by Chironomidae, and Leptohyphidae (Ephemeroptera). In general, the highest invertebrate densities were observed on the last days of the experiment: day 30 for $T$. aurea and day 15 for A. pyrifolium.

The total biomass of invertebrates was higher in $A$. pyrifolium litter $(529.2 \mathrm{mg})$ than in T. aurea litter $(274.3$ $\mathrm{mg}$ ) (Tab. 2, Fig. 2). A. pyrifolium litter presented higher biomass of invertebrates in the initial period of the experiment (days 3 and 7, with $150.7 \mathrm{mg}$ and $293.9 \mathrm{mg}$, respectively), while the biomass of invertebrates in $T$. aurea litter was higher on days 7 and $15(85.6 \mathrm{mg}$ and $110.3 \mathrm{mg}$, respectively) (Fig. 2). The total invertebrate richness associated with leaf litter was similar between species throughout the experiment $(\mathrm{P}>0.05)$.

\section{Functional feeding groups}

The composition of functional feeding groups varied between tree species according to incubation time (Tab. 3,
Fig. 4). Collectors were the most frequent (50\%) in the litter in both species, followed by filters, scrapers and predators (Fig. 4). Filters (45\%) were the most representative in the litter of $T$. aurea, followed by collectors, scrapers and predators. For A. pyrifolium, the most representative group

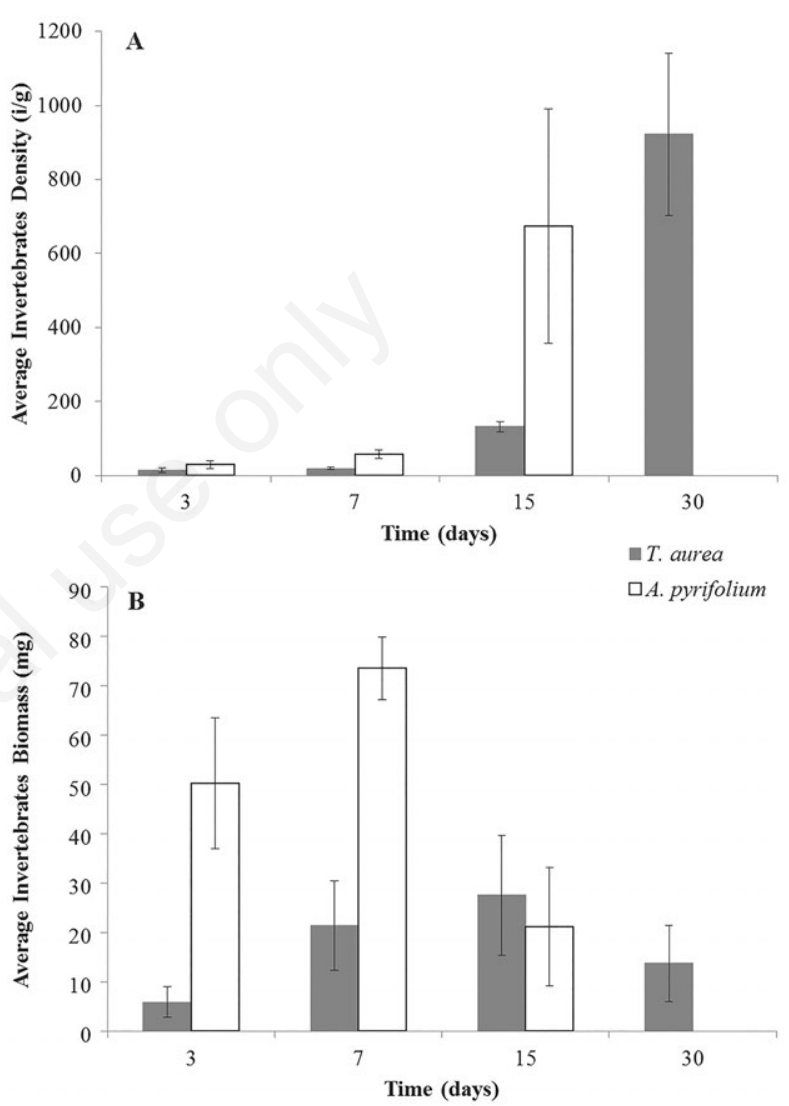

Fig. 3. Density (A) biomass (B) average invertebrate associated with Tabebuia aurea and Aspidosperma pyrifolium incubated in litter bags in a Brazilian semiarid stream.

Tab. 2. Two-way ANOVA for density and biomass of associated invertebrates of Tabebuia aurea and Aspidosperma pyrifolium leaves in a Brazilian semiarid stream.

\begin{tabular}{|c|c|c|c|c|c|}
\hline Density & df & SS & MS & F & $\mathbf{P}$ \\
\hline Species & 1 & 2.03 & 2.03 & 4.45 & 0.047 \\
\hline Time & 3 & 57.63 & 19.21 & 42.12 & $<0.001$ \\
\hline Species:Time & 2 & 0.54 & 0.27 & 0.59 & 0.561 \\
\hline Residuals & 20 & 9.12 & 0.46 & & \\
\hline Biomass & df & SS & MS & $\mathbf{F}$ & $\mathbf{P}$ \\
\hline Species & 1 & 9140 & 9140 & 11.46 & 0.003 \\
\hline Time & 3 & 4834 & 1611 & 2.02 & 0.142 \\
\hline Species:Time & 2 & 1702 & 1702 & 2.13 & 0.159 \\
\hline Residuals & 20 & 16757 & 798 & & \\
\hline
\end{tabular}


was the collectors $(68 \%)$ followed by filters and scrapers We did not find predators in A. pyrifolium (Fig. 4).

The density of filters and collectors was higher in $T$. aurea throughout the leaf incubation time (Tab. 4). The biomass of collectors increased with time and peaked on day $15(\sim 60 \%)$ in $T$. aurea litter. On the other hand, in $A$. pyrifolium litter, the biomass of collectors peaked on day 3 ( $75 \%)$ (Tab. 4). The density of scrapers varied throughout the incubation time, with maximum values for both species observed during the final days of the experiment. The scraper biomass was higher in $A$. pyrifolium litter $(10.6 \mathrm{mg})$ than in T. aurea litter $(4.4 \mathrm{mg})$ (Tab. 4)

\section{DISCUSSION}

Our results indicate that the differences in the physical structure and chemical composition of T. aurea and $A$. pyrifolium leaf litter influenced the density and biomass of associated invertebrates, and also the composition of functional feeding groups. Foliar toughness; $\mathrm{N}$ content; and $\mathrm{Mg}, \mathrm{Ca}$ and $\mathrm{K}$ contents were the most varying leaf traits between $T$. aurea and A. pyrifolium and contributed to the colonization of the organisms. Due to the high amount of N, low C:N ratio and low toughness, $A$. pyrifolium was considered to have leaves of better nutritional quality for invertebrates than those of $T$. aurea, as the leaves of A. pyrifolium decomposed faster and were therefore more effective for the colonising agents.

The development of mechanical, chemical and tolerance defences, based on plant morphology and physiology, is intended to protect plants against unfavourable environmental conditions (Lucas et al., 2000; Schoonhoven et al., 2005; Fürstenberg-Hägg et al., 2013; Dourado et al., 2016). Mechanical defences confer resistance and toughness to plants and act to prevent contact between herbivores and the attacked parts (Lucas et al., 2000).

It is important to emphasise that the structural and chemical characteristics of plant species in the semiarid region result from different adaptive strategies regarding maintenance in environments under water scarcity (Trovão et al., 2007). Compared to wet systems, arid and semi-arid systems select morphophysiological adaptations for water availability, avoiding thermal stress (Tomlinson et al., 2013). However, such adaptations do not necessarily imply in tough tissues, as was the case of $A$. pyrifolium, which invests in other adaptations rather than foliar toughness such as accumulation of leaf nitrogen (Aquino et al., 2017), which may lead to greater attractiveness to invertebrates. Moreover, even species that depend on drought adaptations do not necessarily allocate resources to more complex and difficult to decompose tissues.

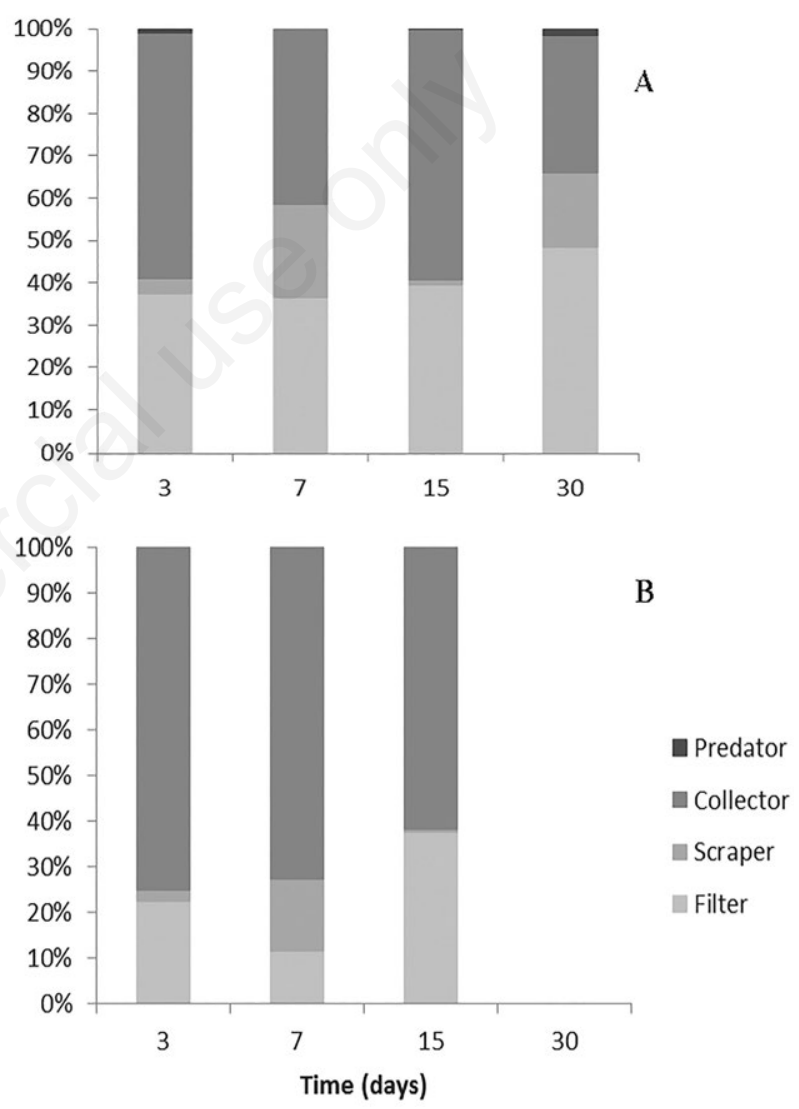

Fig. 4. Percentage of density of functional feeding groups of invertebrates associated with (A) Tabebuia aurea and (B) Aspidosperma pyrifolium in a Brazilian semiarid stream.

Tab. 3. Permanova for the composition of trophic invertebrate groups associated with leaves by species (Tabebuia aurea and Aspidosperma pyrifolium) and by incubation time (3, 7, 15 and 30 days) in a Brazilian semiarid stream.

\begin{tabular}{lcccccc} 
& df & SS & MS & F-Model & P \\
Species & 1 & 0.12 & 0.12 & 3.99 & $\mathbf{0 . 0 1 6}$ & $\mathbf{0 . 0 0 1}$ \\
\hline Time & 3 & 0.45 & 0.15 & 5.10 & $\mathbf{0 . 0 3 2}$ \\
\hline Species:Time & 2 & 0.16 & 0.08 & 2.67 &
\end{tabular}


The chemical composition and higher toughness of $T$. aurea reflect a greater investment in defence and/or adaptation mechanisms compared with those of $A$. pyrifolium. T. aurea leaves present an epidermis and degree of lignification that confer greater resistance to decomposition and/or damage by herbivores. The epidermis of the T. aurea leaves is cuticularised (uni- and biserial) (Silva et al., 2009) and has a broad anatomical plasticity that allows a high capacity for water regulation (Dousseau et al., 2008), which are important features in species that inhabit semiarid regions. A. pyrifolium invests in other leaf traits as a strategy to support water scarcity and predator attack: leaves are more tender and softer (Tab. 1). Leaves of $A$. pyrifolium are characterized by a lower investment in epidermal and support tissues, a fact probably related to foliar longevity. Malleable leaves denote little investment of the plant which characterizes this organ lesser life (Larcher, 2000). In fact, Amorim et al. (2009) found different foliar phenotypes for both species. In addition, $A$. pyrifolium leaves accumulate higher levels of $\mathrm{N}$ and phenolic compounds in drier periods, a strategy that reduces herbivory rates in periods of higher leaf fall (Aquino et al., 2017). However, the faster leaching of phenolic compounds in the early days of aquatic decomposition may favor colonization by invertebrates, and accelerate rates of decomposition.
Leaf toughness is a determining factor in the rate of foliar decomposition in streams (Li et al., 2009). Tough leaves may prevent their use as a food resource by benthic invertebrates due to the difficulty of being punctured compared with softer leaves (Graça et al., 2001). The higher biomass of organisms in A. pyrifolium litter may indicate positive effects of better quality and lower toughness, facilitating the association of aquatic invertebrates.

Another important factor regarding the colonization of invertebrates is the nutrient content of leaf litter (Graça et al., 2001; García-Palacios et al., 2015). In tropical streams, Pettit et al. (2012) reported a positive correlation between $\mathrm{N}$ content in the leaves and the rates of colonization by aquatic invertebrates, corroborating our results. The leaf litter of $A$. pyrifolium had higher invertebrate biomass and, consequently, higher rates of decomposition. In addition, greater foliar contents of $\mathrm{Mg}$ and $\mathrm{Ca}$ were observed in $A$. pyrifolium; these elements are important micronutrients that are commonly underestimated in the colonization of invertebrates (García-Palacios et al., 2015). Therefore, $A$. pyrifolium leaf litter may have been used more as a food resource by invertebrates than $T$. aurea.

However, the current velocity of the stream, which is inherent to the morphological structure of the stream, may have potentiated a more intense mass loss for both species

Tab. 4. Two-way ANOVA for density and biomass of functional feeding groups by species (Tabebuia aurea and Aspidosperma pyrifolium) and incubation time $(3,7,15$ and 30 days $)$ in a Brazilian semiarid stream.

\begin{tabular}{|c|c|c|c|c|c|c|c|c|}
\hline \multirow[b]{2}{*}{ Filter } & \multicolumn{4}{|c|}{ Density } & \multicolumn{4}{|c|}{ Biomass } \\
\hline & df & SS & F & $\mathbf{P}$ & Df & SS & F & $\mathbf{P}$ \\
\hline Species & 1 & 1.36 & 1.44 & 0.244 & 1 & 0.01 & 0.01 & 0.920 \\
\hline Time & 3 & 76.50 & 27.08 & $<0.001$ & 3 & 2.60 & 0.96 & 0.430 \\
\hline Species:Time & 2 & 3.74 & 1.99 & 0.163 & 2 & 0.10 & 0.05 & 0.948 \\
\hline Residuals & 20 & 18.83 & & & 20 & 18.02 & & \\
\hline \multicolumn{9}{|l|}{ Scraper } \\
\hline Species & 1 & 1.79 & 3.66 & 0.070 & 1 & 5.91 & 6.66 & 0.018 \\
\hline Time & 3 & 56.67 & 38.61 & $<0.001$ & 3 & 8.59 & 3.22 & 0.044 \\
\hline Species:Time & 2 & 0.28 & 0.29 & 0.751 & 2 & 1.30 & 0.73 & 0.493 \\
\hline Residuals & 20 & 9.78 & & & 20 & 17.77 & & \\
\hline \multicolumn{9}{|l|}{ Collector } \\
\hline Species & 1 & 4.80 & 15.98 & $<0.001$ & 1 & 6.01 & 7.54 & 0.012 \\
\hline Time & 3 & 49.69 & 55.12 & $<0.001$ & 3 & 3.94 & 1.65 & 0.210 \\
\hline Species:Time & 2 & 0.12 & 0.20 & 0.823 & 2 & 9.33 & 5.86 & 0.010 \\
\hline Residuals & 20 & 6.01 & & & 20 & 15.94 & & \\
\hline \multicolumn{9}{|l|}{ Predator } \\
\hline Species & 1 & 1.99 & 5.12 & 0.035 & 1 & 0.01 & 2.08 & 0.165 \\
\hline Time & 3 & 10.10 & 8.68 & $<0.001$ & 3 & 0.01 & 0.81 & 0.501 \\
\hline Species:Time & 2 & 0.03 & 0.04 & 0.961 & 2 & 0.00 & 0.69 & 0.515 \\
\hline Residuals & 20 & 7.76 & & & 20 & 0.07 & & \\
\hline
\end{tabular}


during the first days of the experiment. Menéndez et al. (2001) reported up to a $40 \%$ mass loss during the first 3 days of an experiment in tropical streams due to the stream current. In our study, after the first 3 days of incubation, mass loss rates of up to $50 \%$ were achieved by $A$. pyrifolium. Current velocity acts on the litter accelerating the process of leaching of dissolved organic matter. As tannin concentrations were similar between both species, the action of the current may have accelerated the dissolution of phenolic compounds, which are mostly water soluble. This may have contributed to the representative mass loss during the initial days of the experiment. In addition, the temperature of the stream water may have increased the leaching effect of the compounds (Park and Cho, 2003). High temperatures common in semiarid regions influence leaching and accelerate the loss of compounds such as $\mathrm{K}$, which is rapidly lost during the leaching of plant litter (Park and Cho, 2003).

The largest biomass of invertebrates was observed in A. pyrifolium litter, indicating that larger organisms were associated with the leaf litter of this species. This result, together with the lower toughness, lower $\mathrm{C}: \mathrm{N}$ ratio and the higher concentrations of $\mathrm{Mg}$ and $\mathrm{Ca}$ in the leaf litter of this species, suggests that $A$. pyrifolium leaf litter was used as a food resource. Thus, our initial hypothesis that the best-quality plant species would present higher density and biomass of associated invertebrates was accepted. So, we can conclude that the organisms associated with this litter may be using it as a food resource, despite these organisms not being typical shredders.

The differences observed in the compositions of the functional feeding groups of invertebrates can be explained by $T$. aurea leaf litter representing a more resistant substrate to decomposition for invertebrates (Dudgeon and $\mathrm{Wu}$, 1999). In addition, T. aurea litter could constitute a refuge against predators due to its high degree of toughness and its morphological characteristics such as the sickle-shaped leaves. In a field experiment involving fish predation, Ruetz et al. (2002) reported greater leaf invertebrate presence, which resulted in higher rates of decomposition. Thus, our results can be interpreted also in light of the refuge model for predator-prey dynamics (Gause et al., 1936). This model predicts that habitats with refuges can facilitate prey survival in the face of predation. The low density of predators in the leaf litter suggests that $T$. aurea and $A$. pyrifolium leaf litter may be functioning also as a refuge for aquatic invertebrates. Thus, leaf litter can act as a substrate and shelter against predators as well as a food resource in environments where allochthonous organic matter does not have a continuous input throughout the year, such as in aquatic environments in semiarid regions.

In contrast to our hypothesis, we did not record shredders in our study. These organisms are responsible for fragmenting leaf litter, transforming the coarse particulate organic matter into fine particles. However, Shredders are naturally scarce in the tropics (Boyero et al., 2011), and the absence of shredders is ordinarily associated with poor quality of leaf litter compared with that of temperate regions (Janke and Trivinho-Strixino, 2007; Graça and Cressa, 2010). Thereby, this may have contributed to the absence of such functional feeding group in our study.

The dominance of collectors in the leaf litter of both species corroborates other results reported for tropical streams (Mathuriau and Chauvet, 2002; Li et al., 2009; Pettit et al., 2012). This dominance reflects the general eating habits of this group (Barbour et al., 1996). The increase in the density of scrapers in the last few days of the experiment can be explained by the presence of periphyton on the leaf surfaces (Graça et al., 2001), although this was not measured. High presence of scrapers has also been reported in areas with high current velocity (Wallace and Eggert, 2009). Thus, our results suggest that the composition of functional feeding groups of invertebrates reflects the variation in the quality and structure of leaf litter.

\section{CONCLUSIONS}

The two-plant species present significant differences in structure (toughness) and chemical composition (especially $\mathrm{N}, \mathrm{Mg}$ and $\mathrm{Ca}$ contents) of their leaf litter. The variation in these leaf traits affected invertebrate density and biomass. Furthermore, we observed higher density and biomass of invertebrates and, consequently, higher rates of decomposition in the leaf litter with better nutritional quality and lower toughness. The leaf traits of the plant species used also reflected variation in the compositions of functional feeding groups of associated invertebrates.

In a climate change/extreme events scenario, areas with more inhospitable characteristics, such as semiarid and arid regions, cause organisms to develop adaptive/evolutionary strategies that guarantee their reproductive success. The plant species of the semiarid regions present different ecophysiological characteristics to combat the effects of drought and the action of herbivores. These ecophysiological changes include tough leaves that have less nutritional quality. From the perspective of ecosystem functioning of streams, riparian zones that have floristic composition may be problematic regarding the energy maintenance of these aquatic systems. Furthermore, benthic communities show an important trophic plasticity to adapt to the scarcity of allochthonous resources or poor-quality resources. These are the first results of the influence of leaf traits on invertebrate colonization in the streams of semiarid 
regions, and reinforce the need for studies to verify the contribution of organic matter as well as the feeding preferences of invertebrates.

\section{ACKNOWLEDGMENTS}

We thank the Coordenação de Aperfeiçoamento de Pessoal de Nível Superior (CAPES) for granting scholarship at the master's level. We also thank the Laboratory of Ecology of Benthos (UEPB-Campina Grande-PB), the Biomonitoring Laboratory (URI-Erechim$\mathrm{RS}$ ), the Aquatic Ecology Laboratory (UEPB-Campina Grande-PB) and the Laboratory of Ecophysiology of Semiarid plants (UEPB-Campina Grande-PB) for logistical support, as well as the Postgraduate Program in Ecology and Conservation (PPGEC-UEPB). JM thanks Conselho Nacional de Desenvolvimento Científico e Tecnológico $(\mathrm{CNPq})$ for funding the MCTI/CNPQ/ UNIVERSAL Research Project 14/2014 (446721/2014) and research productivity grants (process 302393/2017-0). LUH received financial support from Conselho Nacional de Desenvolvimento Científico e Tecnológico (CNPq) (process 421632/2016-0) and research productivity grants (process 305203/2017-7).

\section{REFERENCES}

Alvares CA, Stape JL, Sentelhas PC, Gonçalves JLM, Sparovek G, 2013. Köppen's climate classification map for Brazil. Meteorol. Z. 22:711-728.

ANA - Agência Nacional de Águas, 2016. HidroWeb: Sistemas de Informações Hidrológicas. Accessed on: May, 12, 2016. Available from: http://www.snirh.gov.br/hidroweb/

Amorim IL, Sampaio EVSB, Araújo EL, 2009. Fenologia de espécies lenhosas da caatinga do Seridó, RN. Revista Árvore. 33:491-499.

Anderson JD, Ingram JSI, 1996. Tropical soil biology and fertility: A handbook of methods. CAB Int., Wallingford: $171 \mathrm{pp.}$

Barbour MT, Gerritsen J, Griffith GE, Frydenborg R, Mccarron E, White JS, Bastian ML, 1996. A framework for biological criteria for Florida streams using benthic macroinvertebrates. J. N. Am. Benthol. Soc. 15:185-211.

Bataglia OC, Furlani AMC, Teixeira JPF, Furlani PR, Gallo JR, 1983. [Métodos de análise química de plantas].[Report in Portuguese]. Instituto Agronômico, Campinas: 48 pp.

Bernaschini ML, Moreno ML, Pérez-Harguindeguy N, Valladares G, 2016. Is litter decomposition influenced by forest size and invertebrate detritivores during the dry season in semiarid Chaco Serrano? J. Arid Environ. 127:154-159.

Bessa MAP, Medeiros JF, 2011. [Levantamento florístico e fitossociológico em fragmentos de caatinga no município de Taboleiro Grande-RN].[Article in Portuguese]. Geotemas 1:69-83.

Boyero L, Pearson RG, Dudgeon D, Graça MAF, Gessner MO, Albarino RJ, Ferreira V, Yule CM, Boulton AJ, Arunachalan M, Callisto M, Chauvet E, Ramirez A, Chará J, Moretti MS,
Júnior JFG, Helson JE, Chará-Serna AM, Encalada AC, Davids JN, Cornejo A, Li AOY, Buria LM, Villanueva VD, Zuniga MC, Pringle CM. 2011. Global distribution of a key trophic guild contrasts with common latitudinal diversity patterns. Ecology 92:1839-1848.

Cepeda-Pizarro JG, 1993. Litter decomposition in desserts: an overview with an example from coastal arid Chile. Rev. Chil. Hist. Nat. 66:323-336.

Coley PD, Barone JA, 1996. Herbivory and plant defenses in tropical forests. Annu. Rev. Ecol. Evol. Syst. 27:305-335.

Dourado ACP, Sa-Neto RJ, Gualberto SA, Corrêa MM, 2016. [Herbivoria e características foliares em seis espécies de plantas da Caatinga do nordeste brasileiro].[Article in Portuguese]. Rev. Bras. Biocienc. 14:145-151.

Dousseau S, Alvarenga AA, Castro EM, Soares RP, Emrich EB, Melo LA, 2008. [Anatomia foliar de Tabebuia serratifolia (Vahl) Nich. (Bignoniaceae) propagadas in vitro, in vivo e durante a aclimatização].[Article in Portuguese]. Ciênc. Agrotec. 32:1694-1700.

Dudgeon D, Wu KKY, 1999. Leaf litter in a tropical stream: food or substrate for macroinvertebrates? Arch. Hydrobiol. 146:65-82.

Fernandez HR, Domingues E, 2001. [Guía para la determinación de los artrópodos bentónicos sudamericanos].[Book in Spanish]. UNT, Tucumán: 282 pp.

Frauendorf TC, Colón-Gaud C, Whiles MR, Barnum TR, Lips KR, Pringle CM, Kilham SS, 2013. Energy flow and the trophic basis of macroinvertebrate and amphibian production in a neotropical stream food web. Freshwater Biol. 58:1340-1352.

Fürstenberg-Hägg J, Zagrobelny M, Bak S, 2013. Plant defense against insect herbivores. Int. J. Mol. Sci. 14:10242-10297.

García-Palacios P, Mckie BG, Handa IT, Frainer A, Hättenschwiler S, 2016. The importance of litter traits and decomposers for litter decomposition: a comparison of aquatic and terrestrial ecosystems within and across biomes. Funct. Ecol 30:1-11.

Gause GF, Smaragdova NP, Witt AA, 1936. Further studies of interaction between predators and prey. J. Animal Ecol 5:1-18.

Gonçalves JFJr, Callisto M, 2013. Organic matter dynamics in the riparian zone of a tropical headwater stream in Southern Brasil. Aquat. Bot 109:8-13.

Graça MAS, 2001. The role of invertebrates on leaf litter decomposition in streams - a review. Int. Rev. Hydrobiol. 86:383-393.

Graça MAS, Cressa C, 2010. Leaf quality of some tropical and temperate tree species as food resource for stream shredders. Int. Rev. Hydrobiol. 95:27-41.

Graça MAS, Zimmer M, 2005. Leaf toughness, p. 121-126. In: M.A.S. Graça, F. Bârlocher and M.O. Gessner (eds.), Methods to study litter decomposition: A practical guide. Springer, Dordrecht.

IPCC, 2012. Managing the risks of extreme events and disasters to advance climate change adaptation. A Special Report of Working Groups I and II of the Intergovernmental Panel on Climate Change. Cambridge University Press: 582 p.

IPCC, 2014. Climate Change 2014: Mitigation of climate change. Contribution of working group III to the fifth assessment report of the intergovernmental panel on climate change. Cambridge University Press: 1945 pp. 
Janke H, Trivinho-Strixino S, 2007. Colonization of leaf litter by aquatic macroinvertebrates: a study in a low order tropical stream. Acta Limnol. Bras. 19:109-115.

Larcher W, 2000. [Ecofisiologia vegetal]. Translated by Prado CHBA. Rima, São Carlos: 531 pp.

Li AOY, Ng LCY, Dudgeon D, 2009. Effects of leaf toughness and nitrogen content on litter breakdown and macroinvertebrates in a tropical stream. Aquat. Sci. 71:80-93.

Lucas PW, Turner IM, Dominy NJ, Yamashita N, 2000. Mechanical defences to herbivory. Ann. Bot. 86:913-920.

Marcarelli AM, Baxter CV, Mineau MM, Hall RO, 2011. Quantity and quality: Unifying food web and ecosystem perspectives on the role of resource subsidies in freshwaters. Ecology 92:1215-1225.

Marengo J, Bernasconi M, 2015. Regional differences in aridity/drought conditions over Northeast Brazil: present state and future projections. Clim. Change 129:103-115.

Mathuriau C, Chauvet E, 2002. Breakdown of leaf litter in a neotropical stream Journal of the North America. J. N. Am. Benthol. Soc. 21:384-396.

Menéndez M, Martínez M, Hernández O, Comín FA, 2001. Comparison of leaf decomposition in two Mediterranean rivers: a large eutrophic river and an oligotrophic stream (S Catalonia, NE Spain). Int. Rev. Hydrobiol. 86:475-486.

Mugnai R, Nessimian JL, Baptista DF, 2010. [Manual de identificação de macroinvertebrados aquáticos do Estado do Rio de Janeiro].[Book in Portuguese]. Technical Books, Rio de Janeiro: $176 \mathrm{p}$.

Oliveira RC, Silva AS, Ribeiro ARO, Araújo JE, Oliveira OF, Camacho RGV, 2013. List of Angiosperm species of the riparian vegetation of the Apodi-Mossoró river, Rio Grande do Norte, Brazil. Check List 9:740-751.

Park S, Cho KH, 2003. Nutrient leaching from leaf litter of emergent macrophyte (Zizania latifolia) and the effects of water temperature on the leaching process. Korean J. Biol. Sci. 7:289-294.

Pettit N, Davies T, Fellman J, Grierson P, Warfe D, Davies P, 2012. Leaf litter chemistry, decomposition and assimilation by macroinvertebrates in two tropical streams. Hydrobiologia 680:63-77.

Pringle EG, Adams RI, Broadbent E, Busby PE, Donatti CI, Kurten EL, Renton K, Dirzo R, 2011. Distinct leaf-trait syndromes of evergreen and deciduous trees in a seasonally dry tropical forest. Biotropica 43:299-308.

R Core Team, 2016. R: A language and environment for statistical computing. Vienna, Austria: R Foundation for Statistical Computing. URL: https://www.R-project.org/.
Ruetz CR, Newman RM, Vondracek B, 2002. Top-down control in a detritus-based food web: fish, shredders and leaf breakdown. Oecologia 132:307-315.

Safriel U, Adeel Z, Niemeijer D, Puigdefabregas J, White R, Lal R, Winslow M, Ziedler J, Prince S, Archer E, King C, 2005. Dryland Systems, p. 623-662. In: R.M. Hassan, R. Scholes and N. Ash (eds.), Millennium ecosystem assessment. Ecosystems and human well-being: Current state and trends. Island Press, Washington.

Schoonhoven LM, Van Loon JJA, Dicke M, 2005. Insect plant biology. Oxford University Press, Oxford: $440 \mathrm{pp}$.

Sherman C, Grishkan I, Barness G, Steinberger Y, 2014. Fungal community-plant litter decomposition relationships along a climate gradient. Pedosphere. Soil Sci. Soc. China 24:437-449.

Silva AML, Costai MFB, Leite VG, Rezende AA, Teixeira SP, 2009. [Anatomia foliar com implicações taxonômicas em espécies de ipês].[Article in Portuguese]. Hoehnea 36:329338.

Tank JL, Rosi-Marshall EJ, Griffiths NA, Entrekin SA, Stephen MLA, 2010. Review of allochthonous organic matter dynamics and metabolism in streams. J. N. Am. Benthol. Soc. 29:118-146.

Tomlinson KW, Poorter L, Sterck FJ, Borghetti F, Ward D, de Bie S, van Langevelde F, 2013. Leaf adaptations of evergreen and deciduous trees of semi-arid and humid savannas on three continents. J. Ecol.101:430-440.

Trivinho-Strixino S, 2011. [Larvas de Chironomidae: Guia de identificação].[Book in Portuguese]. UFSCar, São Carlos: $371 \mathrm{pp}$.

Trovão DMBM, Fernandes PD, Andrade LA, Dantas Neto JD, 2007. [Variações sazonais de aspectos fisiológicos de espécies da Caatinga].[Article in Portuguese]. Rev. Bras. Eng. Agríc. Ambient. 11:307-311.

Vannote RL, Minshall GW, Cummins KW, Sedell JR, Cushing CE, 1980. The river continuum concept. Can. J. Fish. Aquat. Sci. 37:130-137.

Wallace JB, Eggert SL, 2009. Benthic invertebrate fauna, small streams. Encyclopedia of Inland Waters 2:173-190.

Wantzen KM, Wagner R, 2006. Detritus processing by invertebrate shredders: a neotropical-temperate comparison. J. N. Am. Benthol. Soc. 25:216-232.

Webster J, Benfield EF, 1986. Vascular plant breakdown in freshwater ecosystems. Annu. Rev. Ecol. Evol. Syst. 17:567594.

Westlake DF, 1963. Comparisons of plants productivity. Biol. Rev. 38:385-425. 